\title{
Banimento e reconstrução de si na escritura de Eduardo Galeano
}

Heloísa Miranda ${ }^{1}$

Célia Reis ${ }^{2}$

\begin{abstract}
Resumen: En este artículo analizamos la narrativa "Ecos", de Boca del tiempo (2013), de Eduardo Galeano, en la que presenta, valiéndose de la función poética del lenguaje, la historia del brasileño Frei Tito de Alencar Lima. El análisis, con un carácter estilístico-formal e histórico-político, busca demostrar cómo Galeano compone su narrativa basada en el sufrimiento impuesto a Frei Tito por los agentes de la Dictadura Civil-Militar brasileña, acerca el trauma que adquirió y como la pena de destierro del Territorio Nacional, con el Acto Institucional $N^{o}$ 13/1969, fue un factor agravante para su trauma.
\end{abstract}

Palabras clave: Eduardo Galeano; Destierro; Memoria; Trauma; Narrativa.

Resumo: Neste artigo analisamos a narrativa "Ecos", da obra Boca del tiempo (2013), de Eduardo Galeano, na qual ele apresenta, fazendo uso da função poética da linguagem, a história do brasileiro Frei Tito de Alencar Lima. A análise, de cunho estilístico-formal e histórico-político, busca demonstrar como Galeano compõe sua narrativa com base no sofrimento imposto a Frei Tito por agentes da Ditadura Civil-Militar brasileira, no trauma que adquiriu e como a pena de banimento do Território Nacional, pelo Ato Institucional $\mathrm{N}^{\mathrm{o}} 13 / 1969$, constituiu-se num agravante para o seu trauma.

Palavras-chave: Eduardo Galeano; Banimento; Memória; Trauma; Narrativa.

\section{Introdução}

Eduardo Hughes Galeano é conhecido por sua escrita arduamente engajada e seu vasto conhecimento histórico. A partir de sua percepção a obra de Galeano se compõe de uma singularidade no modo como o autor configura a realidade latino-americana, transformando-a em um campo fecundo para a pesquisa literária. Ao lermos textos como $\mathrm{Me}$ moria del fuego III (1984), Las palabras andantes (1993), Espejos: una historia casi universal (2008) e Los hijos de los días (2012), é possível perceber a sensibilidade que o autor alcança a tratar de temáticas relacionadas: à expatriação; à importância da memória concatenada aos fatos cotidianos; à valorização da cultura ameríndia; aos mitos

1 Doutora em Estudos de Linguagem pela Universidade Federal de Mato Grosso (UFMT). Professora do Instituto Federal de Educação, Ciências e Tecnologias de Rondônia - Campus Vilhena.

2 Doutora em Literatura Brasileira pela UNESP. Pós-doutora em Estudos Comparados de Literaturas de Língua Portuguesa pela Universidade de São Paulo (USP). Docente (Associada IV) do Curso de Graduação em Letras e do Programa de Pós-graduação em Estudos de Linguagem (PPGEL) da Universidade Federal de Mato Grosso (UFMT). 
indígenas; à importância da individualidade do sujeito; à percepção sensível do universo feminino; ao não reconhecimento de si mesmo; à busca pela identidade latino-americana e em relação ao modo de percepção do tempo e da história.

É fato que inúmeros trabalhos já foram realizados partindo de alguns desses eixos temáticos. No entanto, encontramos pesquisas que trazem como axioma a análise do discurso politizado do escritor contra as mazelas políticas, econômicas e sociais, devido ao processo exploratório de colonização da América Latina. Como exemplo podemos encontrar: Figurações do Intelectual Latino-Americano em Las Venas Abiertas de América Latina, de Eduardo Galeano, tese desenvolvida por Lindinei da Rocha Silva, em 2011 e Silencio, voz y escritura en Eduardo Galeano, obra produzida pela canadense Diana Palaversich, em 1995. Contudo, nenhuma busca compreender como Galeano configura sua linguagem, de quais recursos estéticos e linguísticos o autor se vale para a composição de seus textos ou, ainda, como a organização do tecido textual passa a ser um fator fundamental para sua significação.

Destarte, a partir da escritura literária de Galeano, passamos a observar o modo como o autor foi subjetivando a experiência da expatriação (Argentina, 1973; Espanha, 1976) que lhe foi imposta por processos ditatoriais na América Latina, no século XX. Devido a essa subjetivação, a escritura de Galeano passa a ser marcada por um crescente uso da função poética da linguagem, que emerge graças ao seu conhecimento no trato com a estrutura linguística, tanto em relação à escrita de si como à de outros personagens, cuja história acompanhou. Assim sendo, para este artigo, será tomada a narrativa do brasileiro Frei Tito de Alencar Lima, intitulada "Ecos", da obra Boca del tiempo, (2013), com o propósito de compreender como Galeano compõe sua narrativa com o intuito de demonstrar a angústia, a dor, os sofrimentos de Frei Tito, provocados por ações da Ditadura Civil-Militar brasileira, do desenvolvimento do trauma e de como a pena de banimento do Território Nacional, determinada pelo Ato Institucional $\mathrm{N}^{\circ} 13$, de 5 de setembro de 1969, converte-se em um agravante para o fortalecimento da memória traumática, impossibilitando a reconstituição do sujeito.

\section{Sobre a constituição da memória traumática}

De que modo os espaços geográficos percorridos podem nos ajudar na busca pelo reconhecimento ou reconstrução do si mesmo? Como pode uma experiência de banimento ser responsável pelo agravamento de uma experiência traumática? São questões que se erguem da narrativa do uruguaio Eduardo Galeano. Sua escritura se transforma em um receptáculo que devolve à superfície da memória histórica incontáveis personagens, entre elas Frei Tito de Alencar Lima, que figuram no contexto das ditaduras latino-americanas. Com base nesse posicionamento, fica perceptível que não é da perspectiva da macro história que o autor se nutre, mas da micro: são os rastros, de pessoas como nós, que encontramos em seu cosmos literário.

Como Galeano seleciona um fato histórico para compor uma narrativa? O critério adotado na escolha dos eventos se dá a partir de uma relação de alteridade com os agentes históricos. Mas como pode o fato persistir na memória do autor, uma vez que não foi ele quem passou por tais experiências? De acordo com Ricoeur (2014), por ter como aspecto fazer com que a distância e a ausência sejam desfeitas, as "inscrições-afecções" possuem o segredo do enigma do rastro mnemônico que, embora sejam assombradas pela ameaça 
do apagamento dos rastros corticais, conseguem estabelecer uma conexão profunda entre nossa atividade mental e a base contínua de nossa experiência corporal.

Quais experiências podem ser consideradas como confirmação da hipótese da sobrevivência das impressões-afecções além de sua aparição? Neste ponto, a experiência princeps é a do reconhecimento, esse pequeno milagre da memória feliz. Uma imagem acode ao meu espírito; e digo ao meu coração: é ele sim, é ela sim. (RICOEUR, 2014, p. 437)

Ainda que a impressão não tenha sido instituída diretamente no corpo de Galeano, compreendemos que é por ter tido experiências semelhantes, durante a ditadura uruguaia, que se dá o reconhecimento. Hayden White (2008), explicando sobre as formas de configuração do discurso histórico, defende que, quando um texto historiográfico traz a linguagem poética em seu discurso, de modo imperioso, significa que o mundo da experiência foi constituído antes de ser descrito. Logo, é plausível afirmar que são as experiências do autor que lhe permitiram construir sua profunda consciência histórica, conferindo-lhe uma faculdade sensível para a escolha das múltiplas estratégias que compõem sua escritura. Ainda que cada texto nos apresente espaços e cronologia díspares, há um traço comum entre eles: o trauma. São os rastros traumáticos que permitem o estabelecimento de um elo entre os episódios narrados por Galeano. A experiência traumática intensifica as marcas das impressões-afecções, fazendo com que o caminho a ser percorrido em busca da memória feliz não seja tão simples.

É em Freud que buscamos compreender as associações entre trauma e memória. Garcia-Roza (2008), disserta que Freud aborda a memória como um aparelho psíquico dotado de diferentes propriedades. A memória freudiana é uma dimensão essencial do escopo psicanalítico, que se organiza a partir de um processo de estratificação decorrente das diferentes formas de manifestação do aparelho de linguagem. Para a mirada freudiana, o aparelho de linguagem não nasce conosco, mas se forma, paulatinamente, em contato com outros aparelhos. Sua manifestação só é possível em virtude da palavra que adquire significado pela relação estabelecida com uma imagem, ou seja, a palavra não é o objeto, mas uma referência a ele. Ela não nos chega pelos sentidos, mas pelas impressões que são formuladas por meio de associações.

Nesse aparelho, as palavras (ou as representações-palavra) adquirem seu significado pela relação que a imagem acústica do complexo representação-palavra mantém com a imagem visual do complexo formado pelas associações de objeto. (GARCIA-ROZA, 2008, p. 32)

Segundo Garcia-Roza, a relação das associações entre o objeto e a coisa se dá por uma relação sígnica, enquanto a relação entre as associações de objeto e a representação-palavra ocorre por meio de uma ligação significante. Dessa maneira, a memória se estrutura como um complexo de imagens-significantes as quais necessitam da palavra para sua materialidade. Ao se articular como linguagem, a memória passa, portanto, a ser constituída por traços que se formam como imagens mnemônicas do inconsciente. Estes traços são constituídos a partir de uma impressão. Tal impressão é um registro psíquico e neurológico cujo conjunto edifica um sistema particular de signos. É válido ressaltar que esse "sistema de signos", embora possa ser compartilhado em forma de uma memória coletiva, como nos ensina Halbwachs (2003), afetará o sujeito de formas muito singulares e, por isso, o processo de significação pode se dar de infinitas maneiras. 
Em Freud, a impressão, uma vez que é o momento primário da elaboração mnêmica, não pode ser compreendida como estímulo e nem como sensação, mas como uma excitação neurológica. Essa tensão tanto pode ocorrer a partir de uma vontade do sujeito ou por uma motivação externa. Sendo assim, compreendemos que o trauma corresponderá a um conjunto de signos que estão ligados à persistência da impressão-afecção, que acaba por formar uma angústia sentida pelo sujeito. Na sequência, buscaremos compreender esse sistema sígnico traumático da memória de Frei Tito, impressas durante a ditadura.

\section{Ecos}

Se fue, pero se quedó. Fray Tito estaba libre, exiliado en Francia, pero seguía preso en Brasil. Los amigos le decían lo que los mapas decían, que el país de sus verdugos quedaba lejos, al otro lado del océano, pero eso de nada servía: él era el país donde sus verdugos vivían.

Estaba condenado a la cotidiana repetición de su infierno. Todo lo que había ocurrido, volvia a ocurrir. Durante más de tres años, sus torturadores no le dieron tregua. Fuera donde fuese, en los conventos de París y de Lyon o en los campos del sur de Francia, le pegaban patadas en el vientre y culatazos en la cabeza, le apagaban cigarrillos en el cuerpo desnudo y le metían picadura eléctrica en los oídos y en la boca.

Y no se callaban nunca. Fray Tito había perdido el silencio. En vano deambulaba buscando algún lugar, algún rincón del templo o de la tierra, donde no resonaran esos gritos atroces que no lo dejaban dormir, ni lo dejaban rezar las oraciones que antes habían sido su imán de Dios. Y ya no pudo más. Es mejor morir que perder la vida, fue lo último que escribió.

(GALEANO, 2013, p. 310)

É o Frei de ordem Dominicana ${ }^{3}$, Tito de Alencar Lima, brasileiro, nascido em Fortaleza, em 14 de setembro de 1945, que passa a figurar a narrativa de Eduardo Galeano. De acordo com o que consta em sua biografia - Um homem torturado: nos passos de Frei Tito de Alencar ${ }^{4}$ (2014), graças a sua trajetória religiosa e militante como secundarista, Frei Tito ganha relevância política. Em 1963, por ter assumido a direção da Juventude Estudantil Católica ${ }^{5}$ do Nordeste, muda-se de Fortaleza para o Recife. Em 1968, sai da capital pernambucana e vai para São Paulo com o objetivo de cursar Filosofia. Neste mesmo ano, por estar participando do $30^{\circ}$ Congresso da União Nacional dos Estudantes (UNE) é preso pela primeira vez.

Entretanto, o percurso de tortura se inicia em 04 de novembro de 1969, quando Frei Tito é preso pelo delegado Sérgio Paranhos Fleury ${ }^{6}$ e chefe Operação Bandeirantes ${ }^{7}$

3 A Ordo Praedicatorum, conhecida por Ordem Dominicana, originou-se em Toulouse, na França, em 1215, por Domingos de Gusmão (1170-1221), possuindo como propósito a pregação da palavra e mensagem de Jesus Cristo e a conversão de pessoas ao cristianismo. No Brasil, a ordem religiosa chega no período da colonização portuguesa.

4 A obra foi lançada em 14 de abril de 2014, na sessão da Comissão da Verdade do Estado de São Paulo, presidida pelo Deputado Adriano Diogo do Partido dos Trabalhadores (PT), que objetivava apurar os fatos sobre sua tortura e morte.

5 A Juventude Estudantil Católica (JEC) é fundada no Brasil em 1935, por um grupo de mulheres, configurando-se como um organismo especializado em realizar uma integração da juventude por meio da educação formal, a partir de uma perspectiva de piedade e ação cristã.

6 Sérgio Paranhos Fleury (1933-1979), conhecido como Papa, foi o delegado responsável pelo Departamento de Ordem Política e Social (DOPS) de São Paulo, no período de 1968 à 1979. Fleury ficou conhecido por sua atuação violenta e foi acusado de tortura e homicídio de inúmeras pessoas pelo Ministério Público, mas morreu antes de ser julgado.

7 Segundo o historiador Jorge José de Melo (2012), a Operação Bandeirantes (Oban), foi criada em junho de 
(OBAN), acusado de oferecer ajuda a Carlos Marighella ${ }^{8}$, por essa razão, é encaminhado ao Departamento de Ordem Política e Social ${ }^{9}$ (DOPS) de São Paulo, onde foi submetido à palmatória e choques elétricos. Depois de seu primeiro interrogatório, segundo Duarte-Plon e Meireles (2014), Frei Tito é levado para o Presídio Tiradentes, onde permanece sob a custódia da justiça militar por dois meses. Não obstante o delegado Flery já tivesse alcançado seu principal objetivo com a morte de Marighella, em suas investigações, descobre que Frei Tito fora o responsável pelo aluguel do sitio em Ibiúna, local do congresso da UNE, em 1968. Por causa disso, o frade é levado, na tarde de 17 de fevereiro de 1970, do presídio para o DOPS. É em uma carta, clandestinamente escrita, que Frei Tito expõe o primeiro testemunho publicado sobre seus três dias de intensa torturas. $\mathrm{O}$ documento foi construído com a ajuda de Carlos Alberto Libânio Christo, o Frei Betto ${ }^{10}$, alcança a imprensa internacional e é publicado pela revista americana Look e pela revista italiana L'Europeo; pela publicação do texto a revista estadunidense recebeu o prêmio de melhor reportagem, prêmio concedido pela associação da imprensa estrangeira de Nova York.

Eis o relato de Frei Tito, que apresentamos integralmente:

Fui levado do Presídio Tiradentes para a Operação Bandeirantes - Oban (Polícia do Exército) — no dia 17 de fevereiro de 1970, terça-feira, às 14 horas. O capitão Maurício veio buscar-me em companhia de dois policiais e disse: "Você agora vai conhecer a sucursal do inferno". Algemaram minhas mãos, jogaram-me no porta-malas da perua. No caminho as torturas tiveram início: cutiladas na cabeça e no pescoço, apontavam-me seus revólveres. - Ao chegar à Oban, fui conduzido à sala de interrogatórios. A equipe do capitão Maurício passou a acarear-me com duas pessoas. $\mathrm{O}$ assunto era o congresso da UNE em Ibiúna, em outubro de 1968. Queriam que eu esclarecesse fatos ocorridos naquela época. Apesar de declarar nada saber, insistia? para que eu "confessasse". Pouco depois levaram-me para o pau-de-arara. Dependurado, nu, com mãos e pés amarrados, recebi choques elétricos, de pilha seca, nos tendões dos pés e na cabeça. Eram seis os torturadores, comandados pelo

1969, constituiu-se de uma operação de combate a grupos organizados que eram opositores à política e ao regime militar, na região da Grande São Paulo. Seu propósito era identificar, localizar e capturar militantes, denominados de "subversivos" pela ditadura. A operação era composta por militares do Exército, da Marinha e da Aeronáutica, assim como policiais federais, agentes da Secretaria Nacional de Inteligência e por policiais do Delegacia de Ordem Política e Social (DOPS). Melo também nos informa que a Oban contou com o financiamento da iniciativa privada. Em sua dissertação de mestrado, o historiador trata, especificamente, do executivo Henning Albert Boilesen, dinamarquês, naturalizado brasileiro e sua relevância para o financiamento da operação.

8 Carlos Marighella (1911-1969) foi escritor, deputado e militante político, envolveu-se na luta contra o Estado Novo e, mais tarde, contra a Ditadura. Por não concordar mais com as ideologias do Partido Comunista Brasileiro (PCB), Marighella funda, em 1967, a Ação Libertadora Nacional (ALB), cujo objetivo central era treinar cidadãos para a luta armada contra a ditadura. Marighella é assassinado em uma emboscada, em 04 de novembro de 1969.

9 O DOPS, como nos conta a historiadora Larissa Rosa Corrêa (2008), foi formado em 17 de abril de 1924 pela Lei ${ }^{\circ} 2304$, que tratava de reorganizar a Polícia do Estado. Durante o governo de Getúlio Vargas, o Dops se transforma em um órgão cuja função seria o de estabelecer controle político e militar. Já na Ditadura Civil-Militar brasileira, converte-se em uma instituição de inteligência amplamente violenta e é subdivida. Mais tarde, com a publicação do Ato Institucional $N^{\circ} 5$, as ações do Destacamento de Operações de Informação - Centro de Operações de Defesa Interna (DOI-CODI), como passou a ser denominado, ganha legalidade jurídica.

10 Frei Betto é o autor da obra Batismo de Sangue: os dominicanos e a morte de Carlos Marighella (1983), texto ganhador do prêmio Jabuti, de 1983. A obra foi adaptada para o cinema pelo diretor Helvécio Ratton e lançada em 2007. 
capitão Maurício. Davam-me “telefones" (tapas nos ouvidos) e berravam impropérios. Isso durou cerca de uma hora. Descansei quinze minutos ao ser retirado do pau-de-arara. $\mathrm{O}$ interrogatório se reiniciou. As mesmas perguntas, sob cutiladas e ameaças. Quanto mais eu negava, mais fortes as pancadas. A tortura, alternada de perguntas, prosseguiu até as vinte e duas horas. Ao sair da sala, tinha o corpo marcado por hematomas, o rosto inchado, a cabeça pesada e dolorida. Um soldado carregou-me até a cela 3, onde fiquei sozinho. Era uma cela de 3 × 2,5 metros, cheia de pulgas e de baratas. Terrível mau cheiro, sem colchão e cobertor. Dormi de barriga vazia sobre o cimento frio e sujo. - Na quarta-feira, fui acordado às oito horas. Subi para a sala de interrogatórios, onde a equipe do capitão Homero me esperava. Repetiram as mesmas perguntas do dia anterior. A cada resposta negativa eu recebia cutiladas na cabeça, nos braços e no peito. Nesse ritmo prosseguiram até o início da noite, quando me serviram a primeira refeição naquelas 48 horas: arroz, feijão e um pedaço de carne. Um preso, na cela ao lado da minha, ofereceu-me copo, água e cobertor. Fui dormir com a advertência do capitão Homero de que, no dia seguinte, enfrentaria a "equipe da pesada". - Na quinta-feira, três policiais acordaram-me à mesma hora do dia anterior. De estômago vazio, fui para a sala de interrogatórios. Um capitão, cercado por sua equipe, voltou às mesmas perguntas: "Vai ter que falar senão só sai morto daqui!", gritou. Logo vi que isso não era apenas uma ameaça, era quase uma certeza. Sentaram-me na cadeira-do-dragão, com chapas metálicas e fios, descarregaram choques nas mãos, nos pés, nos ouvidos e na cabeça. Dois fios foram amarrados em minhas mãos e um na orelha esquerda. A cada descarga, eu estremecia todo, como se o organismo fosse se decompor. Da sessão de choques passaram-me ao pau-de-arara. Mais choques, pauladas no peito e nas pernas que cada vez mais se curvavam para aliviar a dor. Uma hora depois, com o corpo todo ferido e sangrando, desmaiei. Fui desamarrado e animado. Conduziram-me a outra sala dizendo que passariam a descarga elétrica para 220 volts a fim de que eu falasse "antes de morrer". Não chegaram a fazê-lo. Voltaram às perguntas, batiam em minhas mãos com palmatória. As mãos ficaram roxas e inchadas, a ponto de não ser possível fechá-las. Novas pauladas. Era impossível saber qual parte do corpo doía mais; tudo parecia massacrado. Mesmo que quisesse, não poderia responder às perguntas: o raciocínio não se ordenava mais, restava apenas o desejo de perder novamente os sentidos. Isso durou até as dez horas, quando chegou o capitão Albernaz. - "Nosso assunto agora é especial", disse o capitão Albernaz ligando os fios em meus membros. "Quando venho para a Oban, deixo o coração em casa. Tenho verdadeiro pavor a padre e para matar terrorista nada me impede... Guerra é guerra, ou se mata ou se morre. Você deve conhecer fulano e sicrano (citou os nomes de dois presos políticos que foram torturados por ele). Darei a você o mesmo tratamento que dei a eles: choques o dia todo. Tudo que você não disser, maior a descarga elétrica que vai receber." Estavam três militares na sala. Um deles gritou: "quero nomes e aparelhos". Quando respondi: "não sei”, recebi uma descarga elétrica tão forte, diretamente ligada à tomada, que houve um descontrole em minhas funções fisiológicas. O capitão Albernaz queria que eu dissesse onde estava o Frei Ratton. Como não soubesse, levei choques durante quarenta minutos. Queria os nomes de outros padres de São Paulo, Rio e Belo Horizonte "metidos na subversão". Partiu para a ofensa moral: "quais os padres que têm amantes?", "por que a Igreja não expulsou vocês?", "quem são os outros padres terroristas?" Declarou que o interrogatório dos dominicanos feito pelo DOPS tinha sido "a toque de caixa" e que todos os religiosos presos iriam à Oban prestar novos depoimentos. Receberiam também o mesmo "tratamento". Disse que "a Igreja é corrupta, prática agiotagem, o Vaticano é dono das maiores empresas do mundo". Diante de minhas negativas, aplicavam-me choques, davam-me socos, pontapés e pauladas nas costas. Revestidos de paramentos litúrgicos, os policiais me fizeram abrir a boca "para receber a hóstia sagrada". Introduziram um fio elétrico. Fiquei com a boca toda inchada, sem poder (alar direito. Gritavam difamações contra a Igreja, berravam que os padres são homossexuais porque não se casam. Às 14 horas, encerraram a 
sessão. Carregado, voltei à cela, onde fiquei estirado no chão. - Às dezoito horas serviram o jantar, mas não consegui comer. Minha boca era uma ferida só. Pouco depois levaram-me para uma "explicação". Encontrei a mesma equipe do capitão Albernaz. Voltaram às mesmas perguntas. Repetiram as difamações. Disseram que, em vista de minha resistência à tortura, concluíram que eu era um guerrilheiro e devia estar escondendo minha participação em assaltos a bancos. O "interrogatório" se reiniciou para que eu "confessasse" os assaltos: choques, pontapés nos órgãos genitais e no estômago, palmatória, ponta de cigarro aceso em meu corpo. Durante cinco horas apanhei como um cachorro. No fim, fizeram-me passar pelo "corredor polonês". Avisaram que aquilo era a estréia do que iria ocorrer com os outros dominicanos. Quiseram deixar-me dependurado toda a noite no pau-de-arara. Mas o capitão Albernaz objetou: "Não é preciso, vamos ficar com ele aqui mais dias. Se não falar, será quebrado por dentro, pois sabemos fazer as coisas sem deixar marcas visíveis. Se sobreviver, jamais esquecerá o preço de sua valentia." - Na cela, eu não conseguia dormir. A dor crescia a cada momento. Sentia a cabeça dez vezes maior que o corpo. Angustiava-me a possibilidade de os outros religiosos sofrerem o mesmo. Era preciso pôr um fim àquilo. Sentia que não iria agüentar mais o sofrimento prolongado. Só havia uma solução: matar-me. - Na cela cheia de lixo encontrei uma lata vazia. Comecei a amolar sua ponta no cimento. O preso ao lado pressentiu minha decisão e pediu que eu me acalmasse. Havia sofrido mais do que eu (teve os testículos esmagados) e não chegara ao desespero. Mas, no meu caso, tratava-se desimpedir que outros viessem a ser torturados e de denunciar à opinião pública e à Igreja o que se passa nos cárceres brasileiros. Só com o sacrifício de minha vida isso seria possível, pensei. Como havia um Novo Testamento na cela, li a Paixão segundo São Mateus. O Pai havia exigido o sacrifício do Filho como prova de amor aos homens. Desmaiei envolto em dor e febre. - Na sexta-feira, fui acordado por um policial. Havia a meu lado um novo preso: um rapaz português que chorava pelas torturas sofridas durante a madrugada. O policial advertiu-me: "O senhor tem hoje e amanhã para se decidir a falar. Senão a turma da pesada repete o mesmo pau. Já perderam a paciência e estão dispostos a matá-lo aos pouquinhos." Voltei aos meus pensamentos da noite anterior. Nos pulsos, eu havia marcado o lugar dos cortes. Continuei amolando a lata. Ao meio-dia tiraram-me para fazer a barba. Disseram que eu iria para a penitenciária. Raspei mal a barba, voltei à cela. Passou um soldado. Pedi que me emprestasse a gilete para terminar a barba. $\mathrm{O}$ português dormia. Tomei a gilete, enfiei-a com força na dobra interna do cotovelo, no braço esquerdo. O corte fundo atingiu a artéria. $\mathrm{O}$ jato de sangue manchou o chão da cela. Aproximei-me da privada, apertei o braço para que o sangue jorrasse mais depressa. Mais tarde, recobrei os sentidos num leito do Pronto-Socorro do Hospital das Clínicas. No mesmo dia, transferiram-me para um leito do Hospital Militar. O Exército temia a repercussão, não avisaram a ninguém do que ocorrera comigo. No corredor do Hospital Militar, o capitão Maurício dizia desesperado aos médicos: "Doutor, este padre não pode morrer de jeito nenhum. Temos que fazer tudo, senão estamos perdidos." No meu quarto, a Oban deixou seis soldados de guarda. - No sábado, teve início a tortura psicológica. "A situação agora vai piorar para você que é um padre suicida e terrorista", diziam eles. "A Igreja vai expulsá-lo." Não deixavam que eu repousasse. Falavam o tempo todo, jogavam, contavam-me estranhas histórias. Percebi logo que, a fim de fugirem à responsabilidade de meu ato e o justificarem, queriam que eu enlouquecesse (BETTO, 1987, p. 189-196).

O relato apresentado sem cortes justifica-se porque qualquer seleção lexical não seria suficiente para parafrasear ou interpretar as palavras de Frei Tito. Ele elege os vocábulos para transpor a impressão-afecção em representação-palavra. É o seu conjunto de signos linguísticos que tenta dar conta das sensações de seu corpo. No que tange à narrativa de Eduardo Galeano, embora mantenha uma associação intrínseca com esse episódio, sua 
escritura busca abordar o que ocorreu com frade depois do evento traumático a que foi submetido, iniciando-se com a conclusão do fato: "Se fue [...]."

Segundo Duarte-Plon e Meireles (2014), com o sequestro do embaixador suíço Giovanni Enrico Bücher em janeiro de 1971, Frei Tito e outros 69 presos políticos foram libertados. Contudo, em virtude da assinatura do Ato Institucional $N^{\circ} 13$, em 5 de setembro de 1969, que instituía "a pena de banimento do Território Nacional para o brasileiro que se tornar inconveniente, nocivo ou perigoso à Segurança Nacional e dá outras providências", é que, embora livre, Frei Tito é banido para o Chile de Salvador Allende. De lá ele declara:

O país do samba, futebol e de Pelé é também grande campeão de tortura. A única coisa democrática no Brasil é a tortura porque existe indiscriminadamente para os operários, os sacerdotes, para os advogados e, enfim, para todas as categorias de pessoas (DUARTE-PLON, MEIRELES, 2014, p. 154).

Sua estadia no território chileno dura dois anos, uma vez que, em 1973, Allende é deposto e a ditadura é instaurada em seu país, restando a Frei Tito somente o asilo político na França, no Convento de Sainte-Marie de La Tourette, próximo a cidade de Lyon:

[...] pero se quedó. Fray Tito estaba libre, exiliado en Francia, pero seguía preso en Brasil. Los amigos le decían lo que los mapas decían, que el país de sus verdugos quedaba lejos, al otro lado del océano, pero eso de nada servía: él era el país donde sus verdugos vivían (GALEANO, 2008, p. 305, grifo nosso).

O tecido textual vem nos apresentar a persistência do trauma e a fragilidade psíquica em que Frei Tito se encontrava. Mesmo que algum tempo já tivesse passado, esquecer não era uma realidade possível. O estado quebradiço de seu psiquismo é revelado pela configuração polissindética do primeiro parágrafo. Ao se valer da conjunção adversativa "pero", Galeano instaura o paradoxo: há a liberdade do corpo, mas não a sua alma. A suposta liberdade, ofertada pelo exílio, propicia a formação de uma situação de alienação interior para a qual a experiência da tortura o havia empurrado: “él era el país donde sus verdugos vivían”. É a configuração da paranóia que se materializa na metáfora apresentada pelo texto.

Em Observações psicanalíticas sobre um caso de paranoia. Relato em autobiografia "O caso Schreber", artigo sobre técnicas e outros textos (1911), Freud nos esclarece acerca do conceito de paranoia, dizendo que essa patologia pode ser identificada se o sujeito apresentar qualquer formação delirante que alcance o nível de um sistema, seja ele persecutório, hipocondríaco ou querelante. Entre essas maneiras de delírios, a perseguição pode ser constituída em virtude de um paradoxo intersubjetivo:

O mecanismo de formação de sintoma da paranóia requer que a percepção interna, o sentimento, seja substituído por uma percepção externa. Assim a frase: "Eu o odeio" se transforma, por projeção, nesta outra: "Ele me odeia", me persegue (FREUD, 1911, 54).

É exatamente por se sentir perseguido que Frei Tito acaba produzindo situações em que a perseguição alucinatória se converte em realidade. No entanto, quem o perseguia? "Ouço gritos vindos de lá. São do delegado Fleury. Ele está torturando meus irmãos e prometeu que vai terminar pela minha mãe" (DUARTE-PLON, MEIRELES, 2014, p. 
85). Dunker (2016) explica-nos que, para a psicanálise lacaniana, o diagnóstico de paranoia não pode estar concluído sem a presença de um sintoma que se manifeste no plano da linguagem, ou melhor, sem os fenômenos elementares, esclarecendo-nos que o fenômeno elementar pode ser classificado em delírio de interpretação ou delírio de reivindicação. De acordo com a psicanalista, o delírio de interpretação estaria relacionado com a paranoia e o de reivindicação, à manifestação da esquizofrenia. Sendo assim, sob o ponto de vista lacaniano quanto à manifestação do sintoma por meio da linguagem, Dunker pondera que é comum relacionar a esquizofrenia com alucinações visuais e a paranoia com alucinações auditivas e ressalta: "entre o pólo da voz e o do corpo, o progresso do delírio na paranoia corresponde ao aumento de alucinações visuais (DUNKER, 2016)

Estaba condenado a la cotidiana repetición de su infierno. Todo lo que había ocurrido, volvia a ocurrir. Durante más de tres años, sus torturadores no le dieron tregua. Fuera donde fuese, en los conventos de París y de Lyon o en los campos del sur de Francia, le pegaban patadas en el vientre y culatazos en la cabeza, le apagaban cigarrillos en el cuerpo desnudo y le metían picadura eléctrica en los oídos y en la boca (GALEANO, 2008, p. 305).

Embora estivesse motivado a retomar seus estudos, fazendo planos de viagens para Suécia e Holanda, a sua fragilidade psíquica o impedia de prosseguir: "Estaba condenado a la cotidiana repetición de su infierno". A expressão pleonástica "cotidiana repetición" é o índice da luta que havia sido travada por Frei Tito, desde que deixara o Brasil.

\section{Da composição da estrutura narrativa}

A frase que encerra a conclusão acerca da situação mental do religioso, vista no item anterior, pode ser considerada um aforismo, uma característica da estética de Eduardo Galeano. Ao se valer dessa técnica, o autor consegue condensar várias informações em um mesmo parágrafo. Para a elaboração dessa parte do texto, três pontos devem ser levados em consideração, uma vez que "ler (escutar) uma narrativa não é somente passar de uma palavra a outra, é também passar de um nível a outro (BARTHES, 2013, p. 27)”. Dessa forma, o primeiro nível está relacionado aos espaços percorridos por Frei Tito objetivando uma autocompreensão, um reencontro consigo mesmo - Paris, Lyon, até sua ida ao sul da França: "Veio então o desejo de morar fora do convento. O curso de teologia do seminário foi interrompido. Tito queria ver mais claro dentro de si mesmo. Precisava afastar-se para refletir (DUARTE-PLON, MEIRELES, 2014, p. 188)". O deslocamento espacial é um índice da sua batalha interior e da esperança de que algum lugar lhe pudesse restituir a tranquilidade usurpada.

O segundo nível está associado à temporalidade desse percurso na busca de sublimação do trauma. É válido ressaltar que a temporalidade não se apresenta, no texto de Galeano, apenas em seu aspecto físico - "Durante más de tres años", mas se desdobra em temporalidade traumática. Quem nos explica sobre esse conceito é Cidade e Zornig (2016) que o discutem a luz da teoria freudiana. De acordo com as psicanalistas, o termo se refere às experiências e/ou impressões que podem ser remodeladas em função de novas cenas vivenciadas pelo sujeito, ressaltando que a memória freudiana não se constitui como um elemento inerte, mas é influenciada pela ação de novos elementos, desdobrando-se em novos sentidos: 
O que muda com essa perspectiva é o fato de que a recordação do sujeito não diz respeito à cena exata que ocorreu na realidade, mas ao acesso a um material transformado e processado psiquicamente, que pode continuar a ser modificado ao longo do tempo. Dessa forma, uma experiência passada pode ser ressignificada em um contexto de experiência atual (CIDADE, ZORNIG, 2016, p. 41).

Se a temporalidade traumática está associada à faculdade de reprojetar a cena primária de composição do trauma, e se o material mnemônico não cessa de ser modificado, talvez seja possível afirmar que, considerando o número de vezes que Frei Tito tem acesso via memória ao evento de tortura, teríamos pelo menos um tempo físico potencializado e, como consequência, o reforço profundo do evento traumático.

Cidade e Zornig (2016) concluem dizendo que o tempo traumático é muito diferente do sentido usual da flecha temporal passado, presente e futuro, embora se tenha o costume de pensar o tempo como aquilo que escorre, direcionado por uma seta que só nos permite ir em frente. No tempo traumático nos distanciamos do tempo linear e passamos a cunhar uma temporalidade que condensa paradoxos, unindo, simultaneamente, passado e presente. Preso nesse presente/passado não há possibilidade de visualizar um horizonte. Frei Tito está atado a esse passado contínuo de tortura.

Para a rememoração desses instantes de tortura, outro nível da narrativa se apresenta, o da relação entre o sintagma e o paradigma. Quanto este liame, Roland Barthes (2013) nos ensina que a forma como os elementos estão dispostos na cadeia do texto direciona a maneira como a narrativa será ressignificada pelo leitor. Para tratar desse assunto, Barthes (2013, p.55) explica que, na "língua da narrativa", podemos encontrar distorção em relação aos signos que compõem o enredo. Com a finalidade de esclarecer sua tese, o teórico relaciona a distorção e a expansão dos signos, que Charles Bally em Linguistique génerale et linguistique française (1965) denominou de distaxia sintética ou analítica.

A primeira implica em não realizar uma justaposição das unidades semânticas. Mesmo que haja uma quebra da linearidade sígnica, sua lógica está presente. A ruptura é proposital, uma vez que, "no signo fracionado, seu significado está repartido em diversos significantes [...]. [...] as unidades de uma sequência, embora formando um todo no nível desta mesma sequência, podem ser separadas umas das outras pela inserção de novas unidades.” (BARTHES, 2013, p. 56). A partir dessa análise da teoria de Bally, Barthes (2013, p.56) conclui que a distorção oferece à "língua da narrativa" uma marca própria. Tal marca corresponde a um fenômeno de pura lógica, uma vez que é fundada sobre uma relação e porque mobiliza uma espécie de confiança na memória intelectiva. Ao realizar a distorção, a narrativa deixa de ser uma cópia pura dos acontecimentos relatados, podendo receber inserções, que lhe conferem uma "espécie de tempo lógico, que tem pouca relação com o tempo real, a pulverização das unidades sendo sempre mantida firmemente sob a lógica que une o núcleo da sequência.” (BARTHES, 2013, p. 57).

O horizonte avistado é que há distorção na sequência narrativa do relato de Frei Tito, que pode ser observada na sintaxe, na qual encontramos saltos temporários entre o momento da inscrição do evento traumático, o banimento do país e a ida para a França, a partir da escolha lexical para a descrição das cenas; há inserções na cadeia textual. A narrativa nos oferece encadeamento do tipo: "le pegaban patadas en el vientre y culatazos en la cabeza, le apagaban cigarrillos en el cuerpo desnudo y le metían picadura eléctrica en los oídos y en la boca (GALEANO, 2008, p. 305)”. Colocando em destaque 
os verbos responsáveis pelas ações "pegaban”, "apagaban”, "metían”, é relevante notar que, não obstante o enunciado apresente a indeterminação do sujeito devido à conjugação do verbo na terceira pessoa do plural, de modo irônico, é esta a desinência que lhe confere a indeterminação, e que se converte em índice para a interpretação de que várias pessoas participaram da ação. Como temos acesso ao relato, sabemos que essas pessoas eram o delegado Fleury, o capitão Albernaz e seus subalternos.

Em seguida, observamos como ocorre a construção dos complementos verbais responsáveis pela inteligibilidade da ação verbal: "patadas en el vientre y culatazos en la cabeza", "cigarrillos en el cuerpo desnudo" e "picadura eléctrica en los oídos y en la boca". Como temos verbos transitivos diretos, seus complementos são compostos por substantivos sem a regência preposicional. Contudo, é importante ressaltar o uso dos adjuntos adverbiais que acompanham cada complemento, uma vez que são eles que nos possibilitam realizar uma homologia com o relato de Frei Tito. Portanto, ao tomarmos a teoria barthesiana, podemos depreender que foram essas associações que permitiram que Galeano realizasse outras inserções na sequência narrativa.

Y no se callaban nunca. Fray Tito había perdido el silencio. En vano deambulaba buscando algún lugar, algún rincón del templo o de la tierra, donde no resonaran esos gritos atroces que no lo dejaban dormir, ni lo dejaban rezar las oraciones que antes habían sido su imán de Dios. Y ya no pudo más. Es mejor morir que perder la vida, fue lo último que escribió (GALEANO, 2008, 305).

Para o encerramento da narrativa, Galeano nos traz o estado já consolidado da quebradiça condição psíquica que se encontrava Frei Tito. Em sua biografia, Duarte-Plon e Meireles (2014) descrevem como esse estado persecutório, em Frei Tito, estava latente: "Ao chegar no quarto do Hospital Édouard Herriot, em Lyon, colou-se de frente para a parede, braços abertos em cruz, numa atitude de quem espera pelo fuzilamento. Estou pronto, dizia." (2014, p.015). De acordo com o psicanalista, responsável por seu tratamento, em conferência ${ }^{11}$ proferida em 2011, no Colóquio Linguagem e Violência. O efeito dos discursos sobre a subjetividade de uma época, em Paris, Jean-Claude Rolland informa que Frei Tito passou a cultivar uma ideação suicida, associando a morte à libertação da carne e do espírito. O psicanalista relata que sempre houve um empenho de Frei Tito para conseguir transformar o evento traumático e ressiguinificá-lo. Segundo o psicanalista, embora a tortura física fosse difícil de ser transposta, mais difícil era, para Frei Tito, ultrapassar a tortura psicológica.

E Tito resistiu: isso diz muito de sua força de caráter e sua determinação de viver. O que a tortura emprega de meios físicos, de modo algum pode quebrar um sujeito. Queria chamar a atenção para o fato de que além dos meios físicos, a tortura lança mão de uma arma terrível da qual os torturadores costumam usar de maneira geralmente empírica, até sem saber, mas que, no caso de Tito, tornou-se preponderante, foi içada a altura de método e quase que foi objeto de teoria: "Nós vamos te quebrar por dentro", disse-lhe o delegado Fleury. [...] Até a hora de sua morte, durante todos os anos do exílio, nunca mais se calou a voz do Fleury na cabeça do Tito; em tudo ela o mandava: ir para casa, sair, calar-se, falar, nenhum dos seus gestos escapou mais desse controle. O torturador tinha se imiscuído em sua vítima, fazia

11 Entrevista com o psicanalista Jean-Claude Rolland (2011). 
um corpo só com ela, em uma fusão que não tinha nada de aliança, mas era uma absoluta subjugação. Que a vítima possa se tornar o dobro do torturador, sua sombra, isto é a coisa mais fantástica, a mais insuportável, e ninguém em seu redor tinha como apreciar tamanha metamorfose. (ROLLAND, 2011, p. 78).

A promessa feita pelo delegado Fleury foi cumprida. Frei Tito não consegue, mesmo com o tratamento, reconstituir-se. Em 10 de agosto de 1974, seu corpo é encontrado por um morador de Lyon, sob um álamo, balançando entre o céu e a terra: "Es mejor morir que perder la vida, fue lo último que escribió". A citação de Galeano é uma inscrição deixada por Frei Tito, na capa de sua bíblia.

Nove anos depois, em 25 de março de 1983, o exílio se finda e os restos mortais de Frei Tito voltam para casa. Em uma celebração litúrgica, na Catedral da Sé, em São Paulo, Dom Paulo Evaristo Arns disse: "A morte para o Frei Tito, como para todos nós, é uma libertação total, é o encontro com a liberdade e o amor, sobretudo para aquele que foi torturado. Frei Tito não se matou, ele já havia sido morto pela tortura". Sendo assim, a representação do sofrimento de Frei Tito, por parte da escritura de Eduardo Galeano, é uma encarnação que manifesta o drama de inúmeros brasileiros vítimas do regime militar. Segundo apurações da Comissão da Verdade, foram 1.121 depoimentos, em 80 audiências públicas, em todo o Território Nacional, totalizando a apuração de 434 cidadãos mortos ou desaparecidos.

\section{Algumas considerações finais}

Ao retomarmos a problemática do trauma como uma forma de persistência dos rastros da memória ditatorial, é possível realizar uma associação com o pensamento ricoeuriano, no instante em que o filósofo afirma que é necessário evidenciar que o rastro é o presente do signo de uma causa ausente.

Com a análise da narrativa de Eduardo Galeano, é crível dizer que sua escritura se converte em um condutor mnemônico e, com isso, faz com que o passado não deixe de agir, trazendo para o corpo presente da memória fatos que muitos querem esquecido. Por isso, a vasta obra produzida por Galeano deve ser vista como um signo de persistência dos rastros das memórias ditatoriais, vivenciadas pelos países latinos que compõem a geografia das Américas.

A possibilidade de um esquecimento definitivo, explica-nos Ricoeur (2014), pode ser vista como uma infelicidade existencial que nos convida mais à poesia e a sabedoria do que à ciência, ressaltando que, se o esquecimento tivesse um termo a ser dito no plano do saber, seria, mais uma vez, para questionar a fronteira entre o normal e o patológico. Para o filósofo, a problemática biológica e médica se ergue em um horizonte silencioso da possibilidade da situação limite em que o esquecimento se une ao envelhecimento e à mortalidade.

Portanto, segundo Ricoeur (2014), não seriam apenas os órgãos que permaneceriam no silêncio, mas o próprio discurso científico e filosófico, na medida que continua preso nas redes da epistemologia. E conclui que a filosofia crítica da história e da memória não estão à altura da hermenêutica da condição humana. Talvez tomar o conteúdo histórico se valendo da poeticidade da linguagem seja o meio de deslocar as amarras da epistemologia, colocando em evidência, desse modo, a condição humana.

72 - Conexão Letras, Porto Alegre, v. 15, n. 23, p. 61-73, jan-jun. 2020. 
BARTHES, R.;TODOROV, T; GREIMAS, A. J.; BREMOND, C.; ECO, U. GRITTI, J.; MORIN, V.; METZ,C.; GENETTE, G. Análise estrutural da Narrativa. Rio de Janeiro: Editora Vozes, 2013.

BALLY, Charles. Linguistique générale et linguistique française. 4 ed. Paris: Berna, 1965.

BETTO, Frei. Batismo de Sangue: os dominicanos e a morte de Carlos Marighella. Rio de Janeiro: Editora Bertrand Brasil, 1987.

CIDADE, Natália de Oliveira de Paula. ZORNIG, Silvia Abu-Jamra. Trauma, temporalidade e inscrição psíquica. In: Caderno Psicanalítico. Rio de Janeiro, v. 38, n. 35, p. 29-47, jul./dez. 2016.

DUARTE-PLON, Leneide. MEIRELES, Clarissa. Um homem torturado: nos passos de Frei Tito de Alencar. Rio de Janeiro: Civilização Brasileira, 2014.

FREUD, Sigmund. Observações psicanalíticas sobre um caso de paranóia - obras completas (1911-1913). Vol. 10. São Paulo: Companhia das Letras, 2010.

GALEANO, Eduardo. Memoria del fuego III. Madrid: Siglo XXI, 2013.

. El libro de los abrazos. Madrid: Siglo XXI, 1989.

. Las palabras andantes. Buenos Aires: Siglo XXI, 1993.

. Boca del tiempo. Buenos Aires: Siglo XXI, 2013.

. Espejos: una historia casi universal. Buenos Aires: Siglo XXI, 2008.

. Los hijos de los días. Buenos Aires: Siglo XXI, 2012.

GARCIA-ROZA. A metapsicologia freudiana. Volume 2. A introdução do sonho. 8 ed. Rio de Janeiro: Zahar, 2008.

PALAVERSICH, Diana. Silencio, voz y escritura en Eduardo Galeano. Madrid: Iberoamericana, 1995.

PAZ, Octavio. El arco y la lira. México: Siglo XXI, 2010.

RICOEUR, Paul. A memória, a história e o esquecimento. Tradução de Alain François. Campinas: Editora Unicamp, 2014.

. Do texto a ação: ensaios de hermenêutica II. Lisboa: Diagonal, 1986.

SILVA, Lindinei Rocha. Figurações do intelectual latino-americano em Las venas abiertas de América Latina, de Eduardo Galeano. Tese de Doutorado apresentada ao Programa de Pós-Graduação em Letras Neolatinas da Universidade Federal do Rio de Janeiro UFRJ, em 2011. Disponível em: http://www.letras.ufrj.br/pgneolatinas/media/bancoteses/lindineirochasilvadoutorado.pdf. Acesso em: 04 de maio de 2015.

WHITE, Hayden. Meta-História: A imaginação Histórica do século XIX. Tradução de José Laurêncio de Melo. $2^{\circ}$ Ed. São Paulo: Editora da USP, 2008.

Recebido em: 12/09/2019; Aceito em: 10/10/2019 